\title{
Effect of Lactobacillus rhamnosus LGG and Bifidobacterium animalis subspecies lactis BB-12 combination on the duration of diarrhea and length of hospital stay in children with acute diarrhea in Turkey
}

\section{Türkiye'de akut ishalli çocuklarda Lactobacillus rhamnosus LGG ve Bifidobacterium animalis subspecies lactis BB-12 kombinasyonunun ishal ve hastanede yatış süresi üzerine etkisi}

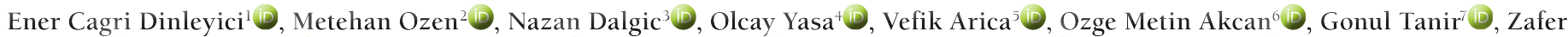

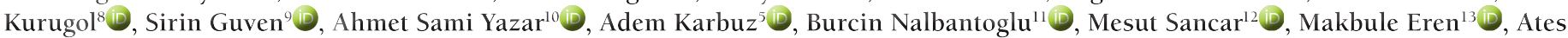
$\operatorname{Kara}^{14}$, Yvan Vandenplas ${ }^{15}$

${ }^{1}$ Dept. of Pediatrics, Eskisehir Osmangazi University Faculty of Medicine, Eskisehir, Turkey, ${ }^{2}$ Acibadem Mehmet Ali Aydinlar University, School of Medicine, Pediatric Infectious Disease Unit, Istanbul, Turkey, ${ }^{3}$ Health Science University, Sisli Etfal Education and Research Hospital, Division of Pediatric Infectious Diseases, Istanbul, Turkey, ${ }^{4}$ Dept. of Pediatrics, Istanbul Medeniyet University, Istanbul, Turkey, ${ }^{5}$ Dept. of Pediatrics, Health Science University, Okmeydani Education and Research Hospital, Istanbul, Turkey, ${ }^{6}$ Dept. of Pediatrics, Necmettin Erbakan Univeristy, Meram Medical Faculty, Division of Pediatric Infectious Diseases, Konya, Turkey, ${ }^{7}$ Dept. of Paediatric Infectious Diseases, Dr Sami Ulus Maternity and Children's Health and Diseases Training and Research Hospital, Ankara, Turkey, ${ }^{8}$ Dept. of Pediatric Infectious Disease, Ege University Faculty of Medicine, Izmir, Turkey, ${ }^{9}$ Dept. of Pediatrics, Health Science University, Sancaktepe Research and Training Hospital Istanbul, Turkey, ${ }^{10}$ Istinye University, VM Medical Park Pendik Hospital, Istanbul, Turkey, ${ }^{11}$ Dept. of Pediatrics, Namik Kemal University, Faculty of Medicine, Tekirdag, Turkey, ${ }^{12}$ Dept. of Clinical Pharmacy, Marmara University Faculty of Pharmacy, Istanbul, Turkey, ${ }^{13}$ Istinye University, Liv Hospital Ulus, Istanbul, Turkey, ${ }^{14}$ Hacettepe University Faculty of Medicine, Pediatric Infectious Disease Unit, Ankara, Turkey, ${ }^{15}$ Dept. of Pediatrics, UZ Brussel, Vrije Universiteit Brussel. Belgium
\end{abstract}

\section{Abstract}

Background Acute diarrhea continues to be a leading cause of morbidity and mortality worldwide. The main therapy for all individuals with dehydration caused by diarrhea is oral rehydration. Probiotics have been proposed as a complementary therapy in the treatment of acute diarrhea. We aim to evaluate the effect of a combination of Lactobacillus rhamnosus GG (LGG) with Bifidobacterium animalis subspecies lactis BB-12 (BB-12) on the duration of diarrhea and length of hospital stay in children with acute diarrhea.

Methods A multicenter, randomized (240 children, 2:1 randomized for probiotic vs. control), single blind, hospitalbased clinical trial was performed in children ( 6 to 60 months) with acute watery diarrhea lasting more than 24 but less than 72 hours, requiring hospitalization. We enrolled children with clinical signs of mild to moderate

Corresponding author: Ener Cagri Dinleyici, Dept. of Pediatrics, Eskisehir Osmangazi University Faculty of Medicine, Eskisehir, Turkey, Phone: +90 222 23929279, E-mail: timboothtr@yahoo.com

Received: 16 May 2020 Accepted: 30 June 2020

Conflict of Interest: None.

Funding: All study products have been supplied by Ferrosan, Turkey. The company have no role on the design, interpretation of the results and writing the manuscript.

How to cite this article: Dinleyici EC, Ozen M, Dalgic N, et al. Effect of Lactobacillus rhamnosus GG and Bifidobacterium animalis subspecies lactis BB-12 combination on the duration of diarrhea and length of hospital stay in children with acute diarrhea in Turkey. Mucosa 2020;3:34-41 
dehydration. The children received conventional therapy with or without the combination of LGG and BB-12 ( $1 \times 10^{9}$ colony forming units for each) for 5 days. The primary endpoint was the duration of diarrhea (in hours), defined as the first normal stool according to the Bristol stool score (score $<5$ ). Secondary outcome measures were duration of hospitalization (days) and percentage of children without diarrhea at 72 hours of intervention.

Results In total, data from 218 of 240 children could be evaluated (150 in the probiotic group and 68 in the control group). The duration of diarrhea was significantly reduced in the LGG and BB-12 group compared to the control group $(74.5 \pm 40.8$ hours vs. $98.4 \pm 22.9$ hours, $P<0.001)$. The percentage of diarrhea-free children was significantly larger in the LGG and BB-12 group at 72 hours compared to the control $(60 \%$ vs. $33.8 \%, P<0.001)$. Mean length of hospital stay was similar for both groups $(5.03 \pm 2.3$ days vs. $5.25 \pm 1.3$ days, $P>0.05$ ).

Conclusion This is the first clinical trial to test the combination of LGG and BB-12, and show its effects on diarrhea duration in children with acute infectious diarrhea. The duration of diarrhea was reduced by approximately 24 hours in the hospitalized children. Further randomized controlled clinical trials including outpatient cases with acute infectious diarrhea in addition to hospitalized cases should be conducted to assess the potential effects of the combination in more detail.

Key words: probiotics, LGG, BB-12, diarrhea, hospitalization, gastroenteritis, Lactobacillus rhamnosus, Lacticaseibacillus rhamnosus

\section{Özet}

Amaç Akut ishal tüm dünyada en önemli morbidite ve mortalite nedenleri arasında yer almaktadır. İshal nedeni ile başvuran tüm hastalarda, dehidratasyonun temel tedavisi oral rehidratasyon sıvisidir. Probiyotikler, akut ishal destek tedavi seçenekleri arasında yer almaktadır. Bu çalışmanın amacı akut ishali olan çocuklarda Lactobacillus rhamnosus GG (LGG) ve Bifidobacterium animalis subspecies lactis BB12 (BB-12) kombinasyonun ishal süresi ve hastanede yatış süresi üzerine etkisinin değerlendirilmesidir. Yöntem Bu çok merkezli, randomize (240 çocuk, probiyotik ile kontrol 2:1 randomizasyon), tek kör çalışma, akut ishal yakınmalarının başlamasından 2472 saat içerisinde hastaneye başvuran, yaşları 6 ay ile 60 ay arasında değişen çocuklarda yapıldı. Çalışmaya hafif ve orta derecede dehidratasyonu olan çocuklar dahil edildi. Çalışmaya dahil edilen çocuklarda, kontrol grubu standart tedavi alırken, probiyotik grubu 5 gün süre ile LGG ve BB-12 (her bir probiyotik $1 \times$ $10^{9}$ koloni) kombinasyonu aldı. Çalışmanın primer sonlanım noktası olarak ishal süresinin Bristol gayta skoru ile takip edilmesi planland. Sekonder sonlanım noktası ise hastanede yatış süresi (gün) ve 72 . saatin sonunda ishal tablosu gerileyen çocuk yüzdesi olarak belirlendi.

Bulgular Çalışmaya katılan 240 çocuğun 218'nin (probiyotik grubunda 150 çocuk, kontrol grubunda 68 çocuk) verileri değerlendirildi. LGG ve BB-12 grubunda ishal süresinin kontrol grubuna göre anlamlı derecede düşük olduğu saptandı (sırası ile $74.5 \pm$ 40.8 saat, $98.4 \pm 22.9$ saat, $P<0.001)$. Çalışmanın 72 . saatinde ishal tablosu gerileyen çocuk yüzdesi LGG ve BB-12 grubunda kontrol grubuna göre belirgin yüksek olduğu saptandı (\%60 vs. \%33.8, P<0.001). Ortalama hastanede yatış süresi gruplar arasında benzer olarak bulundu $(5.03 \pm 2.3$ gün vs. $5.25 \pm 1.3$ gün, $P>0.05)$.

Sonuç LGG ve BB-12 kombinasyonun akut ishal olgularında ilk kez değerlendirildiği bu çalışmada, ishal süresi üzerine olumlu etkilerinin olduğu gösterildi. Hastaneye yatan çocuklarda ishal süresinin yaklaşık 24 saat kısaldı̆̆ı saptandı. Hastaneye yatan çocuklara ek olarak, akut ishal nedeni ile poliklinik başvurusu yapan çocuklarda yapılacak randomize klinik çalışmalar ile bu kombinasyonun etkisi daha detaylı değerlendirilmelidir.

Anahtar kelimeler: probiyotik, LGG, BB-12, ishal, hastaneye yatıs, gastroenterit, Lactobacillus rhamnosus, Lacticaseibacillus rhamnosus

\section{Introduction}

Acute infectious diarrhea is one of the most common causes of morbidity and mortality in children worldwide. ${ }^{1}$ Acute infectious diarrhea is not only a 
leading cause of mortality in developing countries, but also an important reason for hospitalization in these regions. ${ }^{1-2}$ The basic approach to diarrhea treatment is based on the principle of maintaining nutrition (especially breastfeeding in babies who are breastfed), and not using unnecessary drugs (notably antibiotics). This is achieved by replacing and maintaining losses with oral rehydration salts (ORS). ${ }^{2-4}$ ORS treatment has contributed significantly to the decrease in diarrhea morbidity and mortality, especially in developing countries, and WHO recommends using ORS as it is cheap and easily accessible in acute diarrhea cases. ORS is the main approach in the treatment of diarrhea, and it is important to note that all other treatments are additional to ORS therapy. ${ }^{2-4}$ The results of randomized controlled studies prove that probiotics contribute to the treatment of acute diarrhea. ${ }^{4}$ The effects of probiotics in the treatment of acute diarrhea-especially that of viral origin-and its protective effects against antibiotic-associated diarrhea in healthy children have been demonstrated by randomized controlled studies. $^{5-7}$

The type(s) and strain(s) of the microorganism(s) present in the probiotics used in the treatment of acute diarrhea must be fully defined, and clinical effectiveness should be demonstrated via randomized controlled studies. Therefore, the probiotic production process requires advanced technological standards and control over drug and food production technologies. . $^{5,6}$ Studies on the efficacy of probiotics in acute diarrhea have shown that the effect begins within the first 48-72 hours, and it is more rapid in emergency and outpatient patients than in hospitalized children. ${ }^{5-6,9}$ The effects of probiotics on acute infectious diarrhea are strainspecific, and thus, the results of one probiotic strain cannot be extrapolated to another strain. The evidence is minimally supportive of the use of the Bifidobacterium animalis subspecies lactis BB-12 (BB-12) to treat diarrhea. ${ }^{10}$ Many randomized controlled studies have been conducted on Lactobacillus rhamnosus GG (LGG), and several well-conducted meta-analyses about the use of LGG in the treatment of acute diarrhea are now available. ${ }^{10-14}$ Combinations of multiple strains or synbiotics should also be evaluated with clinical studies. Previous studies showed that a combination of LGG and BB-12 could be used safely by healthy children and adolescents. ${ }^{10}$ The evidence regarding coadministration of BB-12 and LGG is also too limited in patients with acute infectious diarrhea. Thus, we conducted a multicenter, randomized, prospective, controlled, and single blind clinical trial to evaluate the effect of LGG and B. BB-12 in children requiring hospitalization due to acute infectious diarrhea.

\section{Patients and Methods}

The PROBAGE study is a multicenter, randomized, single blind, parallel group, controlled, and hospitalbased clinical trial in Turkish children of both sexes, aged between 6 and 60 months, with acute watery diarrhea lasting 12 to 72 hours, requiring hospitalization. The local ethics committee approved the study (2012/4), and written informed consent was obtained from the parents of the children. We enrolled children with clinical signs of mild to moderate dehydration (prolonged capillary refill time, abnormal skin turgor, and percentage loss of body weight). ${ }^{15}$ Subjects with clinical features of hypovolemic shock and/or necessitating admission to the intensive care unit were excluded. Other exclusion criteria were the use of antibiotics or probiotics up to one month before admission, malnutrition (weight under the third percentile), and chronic underlying disease, including immunocompromised conditions.

Using a computer-generated randomization list, all the children were randomly assigned to either the probiotic (Lactobacillus rhamnosus GG (LGG) plus Bifidobacterium animalis subspecies lactis BB-12 (BB12), Bifiform ${ }^{\circledR}$, Pfizer ${ }^{\circledR}$ ) group for 5 days in addition to ORS therapy or the intravenous therapy (control) group. Rehydration and electrolyte replacement were carried out using hypo-osmolar ORS. On admission, the children were clinically examined, and their weight, fever, and degree of dehydration were recorded. The principal site investigator analyzed the results, but did not enroll the children and was blind to their treatment and outcomes. 
The primary endpoint was the duration of diarrhea (in hours). The secondary outcome measures were duration of hospitalization (in days), number of children with diarrhea on each of the 5 days of intervention, and mean frequency of daily stools. The frequency and consistency of the stools were recorded, and the duration of diarrhea was defined as the time in hours from admission until cessation of diarrhea, which was the time when the first normal stool was recorded. The Bristol score was used; a score of less than 5 describes normalization of stool. ${ }^{16}$ The length of hospitalization (time in days from admission until discharge from the hospital) have also been recorded. Statistical analysis was performed using SPSS 16.0 software (SPSS Inc., Chicago, IL, USA). Assuming a mean difference for the duration of diarrhea for 1 day ( 24 hours) between the treatment and control groups, we calculated that a sample of 64 children would be required for each group for the study to have $80 \%$ power with a significance level of 0.05 and a $\sigma$ value of 2 (two-tailed test). We increased the sample size by $10 \%$ to account for potential dropouts, and adopted the 2:1 ratio (probiotic vs. control group). We planned to enroll 240 children (160 children in the probiotic group and 80 children in the control group). The variables were tested for normal distribution and compared using the Mann-Whitney U-test, t-test, and $\chi^{2}$ or Fisher's exact tests, as appropriate. Statistical significance was set at $P<0.05$.

\section{Results}

As explained above, 240 hospitalized children were enrolled, including 160 in the LGG plus BB-12 group and 80 in the control group. Ten children from the LGG plus BB-12 group and 12 children from the control group were excluded because of antibiotic prescription (post randomization), parental refusal to continue the study, and lack of parental compliance). In total, the study proceeded with 150 children in the LGG plus BB-12 (69 boys and 81 girls) group and 68 ( 33 boys and 35 girls) in the control group.

The median age of probiotic group was 11 months (minimum: 3 months, maximum: 60 months), and the median age of the control group was 12 months (minimum: 3 months, maximum: 60 months). Gender and age distribution were similar between the probiotic and control groups ( $P>0.05$ for both). The mean duration of diarrhea before the intervention was similar between the treatment and control groups $(P>0.05)$. The clinical characteristics and severity of gastroenteritis did not differ between the treatment

Table 1. Demographic and clinical findings of the LGG plus BB12 group and control group

\begin{tabular}{|c|c|c|c|}
\hline & $\begin{array}{l}\text { LGG plus BB12 group } \\
\qquad(\mathrm{n}=150)\end{array}$ & $\begin{array}{l}\text { Control Group } \\
\qquad(\mathrm{n}=68)\end{array}$ & $\boldsymbol{p}$ \\
\hline Gender (boys/girls) & $69 / 81$ & $33 / 35$ & $P>0.05$ \\
\hline $\begin{array}{l}\text { Age (months)* } \\
\text { (range:3-60 months) }\end{array}$ & 11 & 12 & $P>0.05$ \\
\hline $\begin{array}{l}\text { Presence of mild /moderate } \\
\text { dehydratation }\end{array}$ & $59 / 91$ & $25 / 43$ & $P>0.05$ \\
\hline $\begin{array}{l}\text { Mean number of stools during the } \\
24 \text { hours prior to inclusion }\end{array}$ & $8.3 \pm 2.9$ & $8.5 \pm 2.9$ & $P>0.05$ \\
\hline Duration of diarrhea (hours)** & $74.5 \pm 40.8$ & $98.4 \pm 22.9$ & $P<0.001$ \\
\hline Length of hospital stay (days)** & $5.03 \pm 2.3$ & $5.25 \pm 1.3$ & $P>0.05$ \\
\hline
\end{tabular}

Values expressed as *median (minimum-maximum); ${ }^{* *}$ mean $\pm \mathrm{SD}$. 
and control groups. The mean of stool frequency during the 24 hours prior to admission was $8.3 \pm 2.9$ per day in the treatment group and $8.5 \pm 2.9$ per day in the control group $(P>0.05)$ (Table 1$)$.

The duration of diarrhea was significantly reduced in the LGG plus BB-12 group compared to the control group (mean + SD) $(\sim 24$ hours, $74.5 \pm 40.8$ hours vs. $98.4 \pm 22.9$ hours, $P<0.001$ ) (Table 1). The effect (diarrhea-free percentage of children) for the LGG plus BB-12 group was first observed in the $48^{\text {th }}$ hour of intervention (Table 2). After 48 hours, 59.3\% of the children receiving LGG plus BB-12 still had watery diarrhea, while this was the case in $83.8 \%$ of the children in the control group $(P<0.001)$. After 72 hours, $39.3 \%$ of the children receiving LGG plus BB12 still had watery diarrhea, and the corresponding value for the control group was $66.1 \%(P<0.001)$. By the $96^{\text {th }}$ and $120^{\text {th }}$ hours of intervention, the diarrheafree percentage of children became similar between the LGG plus BB-12 and the control groups $(P>0.05)$.

Table 2. Percentage of children with diarrhea among the hospitalized children

\begin{tabular}{|c|c|c|c|c|}
\hline & $\begin{array}{l}\text { LGG plus BB-12 } \\
\qquad(\mathbf{n}=150)\end{array}$ & $\begin{array}{l}\text { Control group } \\
\quad(n=68)\end{array}$ & RR (95\% CI) & $p$ \\
\hline $24^{\text {th }}$ hour $(n, \%)$ & $124(82.6)$ & $61(89.7)$ & $0.92(0.83-1.03)$ & $P>0.05$ \\
\hline $48^{\text {th }}$ hour $(n, \%)$ & $89(59.3)$ & $57(83.8)$ & $0.71(0.60-0.84)$ & $P<0.001$ \\
\hline $72^{\text {nd }}$ hour $(\mathrm{n}, \%)$ & $59(39.3)$ & $45(66.1)$ & $0.59(0.46-0.77)$ & $P<0.001$ \\
\hline $96^{\text {th }}$ hour $(n, \%)$ & $28(18.6)$ & $20(29.4)$ & $0.63(0.39-1.04)$ & $P>0.05$ \\
\hline $120^{\text {th }}$ hour (n,\%) & $27(18)$ & $17(25)$ & $0.72(0.42-1.23)$ & $P>0.05$ \\
\hline
\end{tabular}

The mean length of hospital stay was similar for both groups $(5.03 \pm 2.3$ days vs. $5.25 \pm 1.3$ days, $P>0.05)$ (Table 2).

\section{Discussion}

In this study, the combination of LGG and BB-12 reduced the duration of diarrhea within $\sim 24$ hours. The effect of LGG plus BB-12 was first observed after 48 hours of probiotic intervention and the result at the $72^{\text {nd }}$ hour of intervention was also significant. This is the first clinical trial to test the combination of LGG and BB-12, and to show that the effects of this combination in children with acute infectious diarrhea are in line with the reported results in the literature for LGG alone. ${ }^{10,12}$ Szajewska and Hojsak ${ }^{10}$ recently evaluated the efficacy and safety of two common probiotic strains, LGG and BB-12, in children. While four randomized controlled trials (RCTs) involving BB-12, four meta-analyses concerning LGG, three RCTs including LGG, and two RCTs involving a combination of BB-12 and LGG have investigated the effects of these probiotics on acute gastroenteritis (AGE), the studies on LGG and BB-12 combinations have focused only on their preventive effects against AGE. ${ }^{10}$ To the best of our knowledge, this is the first study on the combination of LGG and BB-12 for the treatment of pediatric acute infectious diarrhea.

A number of studies have reported on the effects of LGG alone for the treatment of acute infectious diarrhea. ${ }^{10-14}$ Szajewska et al.'s ${ }^{13,16}$ meta-analyses from 2007 and 2013 revealed that the duration of diarrhea was significantly shorter for children who received LGG versus those who received a placebo. Among the enrolled children, those in the LGG group also 
exhibited decreased risk of diarrhea at 3 days, and a significantly shorter duration of acute diarrhea was observed among those with a confirmed rotavirus infection. Higher doses of LGG ( $\geq 10$ billion colony forming units per day) resulted in a stronger positive effect. ${ }^{17}$ Szajewska et al. ${ }^{12}$ recently updated their metaanalysis, including recently published large study ${ }^{14}$, the pooled results of all the trials found that, overall, LGG can reduce the duration of diarrhea and risk for hospitalization among inpatient populations. Positive opinions about LGG have also been issued via guidelines from international societies and organizations, which recommend adding LGG to rehydration therapy to treat children with AGE. ${ }^{4,}{ }^{18-20}$ In the ESPGHAN and ESPID 2014 guidelines, these effects of probiotics are strain-specific, and the recommended probiotics in the treatment of diarrhea are LGG, Saccharomyces boulardii CNCM I-745, and L. reuteri DSM $17938 .{ }^{4}$ Recently, genome analysis to analyze each Lactobacillus species have been performed. In April 2020, the studied species underwent a name change and is now known as Lacticaseibacillus rhamnosus, but the abbreviation (LGG) remains unchanged. ${ }^{21}$

The PROBAGE study is a multicenter clinical trial in Turkish children, its aim is to evaluate the effects of different probiotic and synbiotic formulations. The aim of the PROBAGE study was to evaluate the selected probiotic strains for the treatment of acute infectious diarrhea. In the first phase of this study, we evaluated Lactobacillus reuteri DSM 17038 (inpatient and outpatient) ${ }^{22-23}$; Bifidobacterium lactis with or without inulin; a combination of Lactobacillus acidophilus, Lactobacillus rhamnosus, Bifidobacterium bifidum, Bifidobacterium longum, Enterococcus faecium and fructooligosaccharide ${ }^{24}$; and Saccharomyces boulardii CNCM-I745 (inpatient, outpatient, and emergency care unit $)^{9}$, and it showed that these probiotics reduced the duration of diarrhea and length of hospitalization. We did not compare the probiotics and synbiotics against each other, we performed comparisons with different controls. In this part of the PROBAGE study, we showed that the combination of LGG and BB-12 reduced the duration of diarrhea in hospitalized children. In the previous parts of the PROBAGE study, we showed that all the probiotic and symbiotic strains reduced the length of hospital stay and affected the duration of diarrhea as well as the percentage of children with diarrhea at the $48^{\text {th }}$ and $72^{\text {nd }}$ hours of intervention..$^{9,22-24}$ However, the combination of LGG and BB-12 had no effect on the duration of hospitalization although an early start of LGG plus BB-12 had an effect on the duration of diarrhea and the percentage of children with diarrhea at the $48^{\text {th }}$ and $72^{\text {nd }}$ hours of intervention. The effects of probiotics thus include shortening of the diarrhea as well hospitalization by 1 day each. This 1-day shortening has been shown to reduce hospital costs. In our country, S. boulardii CNCM I-745 and $L$. reuteri DSM 17938, which were added to the standard treatment for acute rotavirus diarrhea, showed a significant decrease in the cost of hospitalization due to the 1-day shortening of diarrhea, and this effect was much more pronounced in the countrybased projection. ${ }^{25-26}$. These effects will also result in positive effects on parents' work and children's school day losses.

Researchers have proposed numerous mechanisms of probiotic action in acute infectious diarrhea. Different hypotheses have been put forth with the mechanism of action in the use of probiotics against diarrhea. ${ }^{27}$ We recently found $S$. boulardii CNCM-I745 in intestinal microbiota, and its effects are related with the duration of diarrhea. ${ }^{28}$ Following the widespread use of new-generation sequencing technologies and bioinformatics evaluations, many opportunities for investigating new ideas regarding the mechanisms of probiotic action will arise.

Our study also suffers from some limitations. This trial was not a double-blind placebo controlled clinical trial, and we used per-protocol analysis rather than intention-to-treat analysis. We did not identify the pathogens that caused the diarrhea. We also did not perform microbiota analysis.

Probiotics are live microorganisms that, when administered in adequate amounts, confer a health benefit on the host. All probiotic preparations should be evaluated with appropriate clinical trials for potential recommendations. The results of this 
trial showed that the combination of LGG and BB-12 reduced the duration of diarrhea by approximately 1 day. Many researchers have tried to explain the mechanisms behind the positive effects of probiotics on infectious disease treatment. Among these efforts, various studies focused on the effects of probiotics on microbiota restoration. Further randomized controlled clinical trials including outpatient cases with acute infectious diarrhea in addition to hospitalized cases would add to our knowledge about the potential effects of this combination.

\section{Acknowledgement}

Authors thanks to all patients, parents/caregivers for their participation to this study.

\section{References}

1. Global burden of disease 2013 mortality and causes of death collaborators. Global, regional, and national age-sex specific all-cause and cause-specific mortality for 240 causes of death, 1990-2013: a systematic analysis for the Global Burden of Disease Study 2013. Lancet 2015;385:117-71.

2. Florez ID, Nino-Serna LF, Beltran-Arroyave CP. Acute infectious diarrhea and gastroenteritis in children. Curr Infect Dis Rep 2020;22:4.

3. Churgay CA, Aftab Z. Gastroenteritis in children: Part II. Prevention and management. Am Fam Physician 2012;85:1066-70.

4. Guarino A, Ashkenazi S, Gendrel D, Lo Vecchio A, Shamir R, Szajewska H European society for pediatric gastroenterology, hepatology, and nutrition; European society for pediatric infectious diseases. European society for pediatric gastroenterology, hepatology, and nutrition/European society for pediatric infectious diseases evidence-based guidelines for the management of acute gastroenteritis in children in Europe: update 2014. J Pediatr Gastroenterol Nutr 2014;59:132-52.

5. Vandenplas Y. Probiotics and prebiotics in infectious gastroenteritis. Best Pract Res Clin Gastroenterol 2016;30:49-53.

6. Hojsak I, Fabiano V, Pop TL, et al. Guidance on the use of probiotics in clinical practice in children with selected clinical conditions and in specific vulnerable groups. Acta Paediatr 2018;107:927-37.

7. McFarland LV. Deciphering meta-analytic results: a mini-review of probiotics for the prevention of paediatric antibiotic-associated diarrhoea and
Clostridium difficile infections. Benef Microbes 2015;6:189-94.

8. Kolacek S, Hojsak I, Berni Canani R, et al. ESPGHAN working group for probiotics and prebiotics. Commercial probiotic products: A call for improved quality control. A position paper by the ESPGHAN working group for probiotics and prebiotics. J Pediatr Gastroenterol Nutr 2017;65:117-24.

9. Dinleyici EC, Kara A, Dalgic N, et al. Saccharomyces boulardii CNCM I-745 reduces the duration of diarrhoea, length of emergency care and hospital stay in children with acute diarrhoea. Benef Microbes 2015;6:415-21.

10. Szajewska H, Hojsak I. Health benefits of Lactobacillus rhamnosus GG and Bifidobacterium animalis subspecies lactisBB-12 in children. Postgrad Med 2020;26:1-11.

11. Van Niel C, Feudtner C, Garrison MM, Christakis DA. Lactobacillus therapy for acute infectious diarrhea in children: a meta-analysis. Pediatrics 2002;109:678-84.

12. Szajewska H, Kolodziej M, Gieruszczak-Bialek D, Skorka A, Ruszczynski M, Shamir R. Systematic review with meta-analysis: Lactobacillus rhamnosus GG for treating acute gastroenteritis in children - a 2019 update. Aliment Pharmacol Ther 2019;49:1376-84.

13. Szajewska H, Skorka A, Ruszczynski M, Gieruszczak-Bialek D. Meta-analysis: Lactobacillus GG for treating acute gastroenteritis in children-updated analysis of randomised controlled trials. Aliment Pharmacol Ther 2013;38:467-76.

14. Schnadower D, Tarr PI, Casper TC, et al. Lactobacillus rhamnosus $G G$ versus placebo for acute gastroenteritis in children. $\mathrm{N}$ Engl J Med 2018;379:2002-14.

15. Vandenplas Y, De Hert SG, PROBIOTICAL-study group. Randomised clinical trial: the synbiotic food supplement Probiotical vs. placebo for acute gastroenteritis in children. Aliment Pharmacol Ther 2011;34:862-7.

16. Szajewska H, Skorka A, Ruszczynski M, Gieruszczak-Bialek D. Meta-analysis: Lactobacillus GG for treating acute diarrhoea in children. Aliment Pharmacol Ther 2007;25:871-81.

17. Li YT, Xu H, Ye JZ, et al. Efficacy of Lactobacillus rhamnosus $G G$ in treatment of acute pediatric diarrhea: A systematic review with meta-analysis. World J Gastroenterol 2019;25:4999-5016.

18. Cruchet S, Furnes R, Maruy A, et al. The use of probiotics in pediatric gastroenterology: a review of the literature and recommendations by Latin-American experts. Paediatr Drugs 2015;17:199-216.

19. Floch MH, Walker WA, Madsen K, et al. Recom- 
mendations for probiotic use-2011 update. J Clin Gastroenterol 2011;45 Suppl:168-71.

20. World gastroenterology global guidelines. Probiotics and prebiotics. February 2017. https://www. worldgastroenterology.org/UserFiles/file/guidelines/probiotics-and-prebiotics-english-2017.pdf. (Last Access: 15 May 2020).

21. Zheng J, Wittouck S, Salvetti E, et al. A taxonomic note on the genus Lactobacillus: Description of 23 novel genera, emended description of the genus Lactobacillu Beijerinck 1901, and union of Lactobacillaceae and Leuconostocaceae. Int J Syst Evol Microbiol 2020. doi: 10.1099/ijsem.0.004107.

22. Dinleyici EC, PROBAGE Study Group, Vandenplas Y. Lactobacillus reuteri DSM 17938 effectively reduces the duration of acute diarrhoea in hospitalised children. Acta Paediatr 2014;103:e300-5.

23. Dinleyici EC, Dalgic N, Guven S, et al. Lactobacillus reuteri DSM 17938 shortens acute infectious diarrhea in a pediatric outpatient setting. J Pediatr (Rio J) 2015;91:392-6.

24. Dinleyici EC, Dalgic N, Guven S, et al. The effect of a multispecies synbiotic mixture on the duration of diarrhea and length of hospital stay in children with acute diarrhea in Turkey: single blinded randomized study. Eur J Pediatr 2013;172:459-64.

25. Dinleyici EC, Eren M, Yargic ZA, Vandenplas Y. Cost-effectiveness of add-on probiotics (Saccharomyces boulardii) in children with acute rotavirus diarrhea in Turkey (SB-cosTR). $44^{\text {th }}$ annual meeting of the European society for paediatric gastroenterology, hepatology, and nutrition, 25-28 May 2011, Sorrento, Italy, Poster no: PO-G-0085.

26. Dinleyici EC, Kara A, Ozen M, et al. Cost analysis of Lactobacillus reuteri DSM 17938 in children with acute infectious gastroenteritis (PROBAGE Study). J Pediatr Gastroenterol Nutr 2017;64(Suppl 1):432.

27. do Carmo MS , Santos CID , Araujo MC , Giron JA , Fernandes ES , Monteiro-Neto V . Probiotics, mechanisms of action, and clinical perspectives for diarrhea management in children. Food Funct 2018;9:5074-95.

28. Dinleyici EC, Martinez-Martinez D, Kara A, et al. Time series analysis of the microbiota of children suffering from acute infectious diarrhea and their recovery after treatment. Front Microbiol 2018;9:1230. 